\title{
No Change from Climate Change: Vulnerability and Small Island Developing States (SIDS) Ilan Kelman
}

\section{Introduction}

Climate change has been receiving plenty of attention not only as a global crisis but also as perhaps the greatest global crisis that humanity has ever faced (e.g. King 2004). There is no doubt that contemporary climate change, to which human activity contributes significantly (IPCC 2007, 2012), is an immense, long-term concern. Even if all human-related greenhouse gas emissions stopped today, climate change's legacy is likely to be felt for the next millennium (Solomon et al. 2009) meaning that development must factor in climate change (e.g. Grist 2008). Yet the rhetoric emphasising climate change as today's biggest problem might be neglecting the past history of development theory, policy, and practice.

To examine this point, this paper uses the case study of Small Island Development States (SIDS) affected by climate change. This case study is important because it frequently dominates media and policy discussions as being the locations which are amongst the first and worst affected by climate change, potentially to the point of being physically destroyed by climate change's impacts. Yet without denigrating climate change, the wider literature on SIDS nonetheless details many other development challenges beyond climate change.

The main question addressed by this paper is: are SIDS an example of climate change's rhetoric detracting from dealing with wider development problems? The discussion examines whether or not a focus on climate change by researchers, policy-makers and practitioners deflects attention away from underlying political conditions of vulnerability towards the nature of the physical hazard itself (see Arnall et al. 2013, this issue). Potential depoliticisation of development problems due to 
climate change is investigated through examining some dimensions of SIDS' vulnerability to various hazards, including climate change.

Section 2 summarises aspects of vulnerability emerging from earlier literature which are not always credited in contemporary work on climate change and vulnerability in a SIDS context. That leads to three themes of depoliticisation and climate change which are introduced in Section 3 and then detailed in separate sections. First, climate change tends to emphasise the related physical hazards rather than SIDS' vulnerabilities (Section 4). Second, climate change tends to distract from other long-term development challenges (Section 5). Third, climate change tends to shift focus away from opportunities for reducing vulnerability, including during community reconstruction (Section 6). The conclusion highlights that climate change cannot and should not be discarded as a major, threatening hazard to SIDS; rather, climate change should be placed within a wider political context.

\section{Climate change as a depoliticiser}

Investigations of why vulnerability to environmental phenomena leads to disasters have long been in the literature, namely in the realm of disaster studies (see the histories and conclusions in Gaillard 2007, 2010; Hewitt 1983, 1997; Lewis 1999; Oliver-Smith 1986; Wisner et al. 2004, 2012). In a key paper entitled “Taking the 'naturalness' out of natural disasters”, O'Keefe et al. (1976) implicated "the growing vulnerability of the population to extreme physical events" (p. 566), not changes in hazards, as causing the observed increase in disasters. Subsequently, there has been growing acceptance that human actions, behaviour, decisions, governance, and values lead to vulnerabilities which cause disasters, so that disasters are not 'natural' (e.g. GNCSODR 2011; Steinberg 2000). The argument is that nature provides input through environmental events which are potentially hazardous, such as volcanic eruptions, droughts, or climatic trends. But human actions — not just by the people affected directly but also, and more often, by others far removed 
from the consequences of their decisions - have put people and property in harm's way without adequate measures to deal with the hazards.

One of these hazards is climate change, which is a major concern. But it is one major concern amongst many for disaster risk reduction and wider development activities. For instance, disaster vulnerability has significant influences on and from poverty (Hewitt 1983; Wisner et al. 2004, 2012) but poverty reduction cannot be achieved without addressing major development challenges such as land rights (e.g. Deininger 2003) and entitlements (Sen 1981). As another example, for responding to climate change, migration has been receiving prominence as both a climate change adaptation measure and as a failure to adapt, although changes in the climate have long been recognised as one factor amongst many influencing migration decisions (e.g. Bedford and Hugo 2012; Foresight 2011). Whilst some literature (e.g. Bunce et al. 2010) now explicitly recognises that climate change is not the main issue to solve with respect to disaster risk reduction (which itself sits within wider contexts of development), contemporary climate change policy approaches are not always informed by these lessons. Instead, there is too frequently a continuing focus on the external threat of hazards emerging from the changing climate (see the critique in Shaw et al. 2010). Consequently, other disaster and development challenges can be bypassed in policy approaches in order to highlight climate change (see also Gaillard 2010, 2012).

Failing to address concerns wider than climate change, and instead emphasising hazards over vulnerabilities, means that decisions often fail to account for past literature and experience, while not fully addressing root causes of the vulnerabilities to the hazards. These root causes are fundamentally political (e.g. Chambers 1995; Glantz 1976; Hewitt 1983; Lewis 1999; O’Keefe et al. 1976; Sen 1981; Wisner et al. 2004, 2012; see also Arnall et al. 2013, this issue). Although the vulnerabilities tend to be exposed when a hazard manifests, which indeed might be climate change 
or its influences on weather, it is not such hazards per se which are the fundamental problem. Instead, this literature converges on the well-known challenges imbuing all livelihood decisions, highlighting deep-seated problems such as poor resource access, inequity, exploitation, lack of choices available, marginalisation, and injustice.

Therefore, there seems to be little reason to focus principally on climate change. Highlighting climate change (a hazard), rather than the vulnerabilities to all hazards including climate change, and hence the political root causes of the vulnerabilities, depoliticises long-standing and unresolved development challenges (Arnall et al. 2013, this issue). This brief overview of the literature on vulnerability to hazards suggests three principal points of climate change as a depoliticiser which are now explored in this paper: (i) emphasising the hazard, (ii) avoiding other long-term development challenges, and (iii) shifting focus away from opportunities for reducing vulnerability, including during community reconstruction. The remainder of this paper explores these issues in greater depth by focusing on one case study prominent in the debate: SIDS.

\section{Climate change, depoliticisation and SIDS}

SIDS are a group of 52 countries and territories, mainly islands, which were designated by the United Nations to address collectively their development and sustainability concerns (UN 1994, 2005). SIDS are subject to many similar development challenges and adopt similar approaches to address them (Dommen and Hein 1985; Grote 2010; Lewis 1999; Mcgillivray et al. 2008; Méheux et al. 2007; UN 1994, 2005). Many SIDS communities are isolated, small, and depend on natural resources, with local land-based livelihoods tending to be more limited than those provided by the ocean. SIDS peoples have a long history of addressing social and environmental challenges, with varying degrees of success, yielding positive and negative lessons that could apply to dealing with climate change. 
Illustrative climate change impacts on SIDS (Table 1) show that there are many interconnected external and internal factors affecting disaster vulnerability and wider development concerns. External factors include high-end tourism leading to golf courses and luxury hotels (e.g. Barbados), violence associated with drug transhipment and use (e.g. Jamaica) and deforestation for external markets (e.g. Papua New Guinea (PNG)). Internal factors include ethnic tensions (e.g. Fiji), corruption (e.g. Equatorial Guinea), and financial mismanagement (e.g. Nauru). Climate change does not stand alone on SIDS.

\section{Insert Table 1}

The similarities of SIDS are balanced by differences. SIDS' populations range from thousands to millions while areas range from dozens to hundreds of thousands of square kilometres. SIDS can be volcanic with forested slopes, such as Dominica and Montserrat, or can be low-lying atolls, such as the Maldives, with its highest point just 2.4 metres above sea level. Even within SIDS, community sectors can have differing views. For instance, some Tuvaluans do not accept that sea-level rise could inundate them because, in their interpretation of the Bible, God told Noah that there would never be another flood (Farbotko 2005). This attitude is not fatalism, but reflects the reality that flooding from sea-level rise is outside their mental map, culture, and knowledge systems. It is a truism in development that no community is homogeneous (Walmsley 2006), and the same applies to the 'SIDS community' as well as to 'communities within SIDS'.

This heterogeneity politicises different development challenges since different perspectives must be considered and perhaps reconciled. The SIDS case study is now explored through the three themes from Section 2 of climate change as a depoliticiser. 


\section{Climate change emphasises the physical hazard}

Despite extensive disaster research and practice (e.g. GNCSODR 2011; Hewitt 1983, 1997; Lewis 1999; Oliver-Smith 1986; Steinberg 2000; Wisner et al. 2004, 2012) indicating the importance of including vulnerability to all hazards in analysing development challenges, climate change tends to emphasise the hazard leading to negative physical changes to SIDS. For example, without denying the urgency of addressing climate change, for Tuvalu, Connell (2003) and Farbotko (2005, 2010) argue that the media have constructed a discourse of 'drowning' or 'sinking' islands. Webb and Kench (2010) investigated changes over past decades across 27 atoll islands in Kiribati, Tuvalu, and the Federated States of Micronesia, finding a variety of changes, but few examples of an overall decrease in area despite documented sea-level rise. Ballu et al. (2012) demonstrated that geological subsidence dominated sea-level rise for islands of Vanuatu where one village was moved from 2002-2004 and the inhabitants were portrayed by the media as 'climate change refugees'. Rankey (2011) investigated shoreline changes to 17 I-Kiribati atolls, documenting an acceleration of changes in recent years involving a mix of erosion and accretion processes.

These observations do not preclude islands being destroyed by climate change in the future. They indicate the limitations of scientific understanding of the geomorphological responses of SIDS to ongoing climate change - and the variety of observed responses. Constructing a narrative featuring islands that are 'disappearing' due to their physical characteristics and climate change hazards obscures the wider vulnerabilities facing SIDS, sidelining the long-standing literature on this topic (e.g. Lewis 1999; Pelling and Uitto 2001).

As another example, the Maldives' President from 2008-2012, Mohamed Nasheed, highlighted that climate change hazards threaten his country. He committed to setting up a fund to purchase land to 
move Maldivians to-ironic considering that the Maldives' dominant foreign exchange earner is international tourism which is a strong generator of greenhouse gases (Domroes 2001). He also committed the Maldives to becoming carbon neutral by 2020, although it was unclear how fossil fuel use from shipping and aviation (including from international tourism) would be factored into the carbon calculations. In 2009, Nasheed held an underwater cabinet meeting to highlight the drowning islands narrative. The significant threat to the Maldives from climate change is real, but many other development challenges also need to be overcome, such as energy supply (van Alphen et al. 2008) and gender equity (Fulu 2007). Nasheed's focus on climate change provided a convenient distraction from other pressing development difficulties (see also Kothari 2013, this issue).

Another concern with emphasising climate change hazards affecting SIDS is that the hazards are frequently presented as being entirely new. The literature, however, presents previous examples of situations with parallels to climate change. Nunn et al. (2007) document rapid Pacific sea-level changes around 1300 that undermined livelihoods in many island communities leading to their disappearance, either through migration or through being wiped out due to failure to adapt (see also Dickinson 2009). Phenomena related to the El Niño Southern Oscillation (ENSO) led to a major coral reef collapse around Panama’s Pacific from 4,000-1,500 years ago (Toth et al. 2012).

None of these changes represents the baseline change for SIDS that is expected under projected sealevel rise from climate change (Schaeffer et al. 2012). They all indicate events from the past which have parallels with the projected future and which could be used to inform responses to that projected future (see also Glantz 1988) by examining how SIDS societies adapted or did not adapt to the past changes (e.g. Dickinson 2009; Nunn et al. 2007). SIDS are rightly concerned with 
climate change impacts and are right in acting to deal with them, but presenting the projected impacts as an entirely new challenge without precedent neglects past experience and literature.

Trying to attribute SIDS' development problems solely to a new and external climate change hazard shifts the focus away from the wider context of SIDS' vulnerabilities to numerous hazards. These vulnerabilities are long-standing (e.g. Attzs 2008; Ghina 2003; Lewis 1999; Pelling and Uitto 2001), but examples also exist of overcoming the vulnerabilities (e.g. Gaillard 2007; Nakalevu 2006). The key is not to ignore climate change, but to examine it in the context of vulnerabilities to all hazards.

\section{Climate change avoids other long-term development challenges}

In addition to climate change, SIDS face numerous other development challenges (e.g. Lewis 1999; Méheux et al. 2007; Pelling and Uitto 2001; Turvey 2007) which emerge from root causes of vulnerability that are political (e.g. Lewis 1999; Wisner et al. 2004, 2012). Rather than seeking to address the local and external causes of the vulnerabilities, SIDS are frequently iconised as victims of hazards manifesting from climate change (see the deconstructions of such discourse by Barnett and Campbell 2010; Farbotko 2005, 2010; Lazrus 2009). No author denies either the international politics of climate change or SIDS suffering from those international politics which, to a large degree, are beyond their control. Other dimensions also exist, such as SIDS peoples relying on their own knowledge and wisdom to deal with the climate change challenges, along with vulnerabilities to hazards other than climate change.

Nonetheless, media make statements such as 'Kiribati's highest point of land is just $2 \mathrm{~m}$ above sea level" (NZPA 2008) even though Kiribati's highest point is over $80 \mathrm{~m}$ above sea level. The confusion over Kiribati's highest point is surprising since there is no need to exaggerate the difficult situation facing Kiribati. The reality on Kiribati is that the population lives principally in the low- 
lying parts and that the higher parts are not sufficient to sustain the entire population. As such, Kiribati is severely threatened by climate change — along with the ongoing social, livelihoods, and development problems including urban planning, land use, shelter, and water resources (Jones and Lea 2007; Moglia et al. 2007; Olowu 2007). These development challenges exist on Kiribati and need to be solved irrespective of climate change, yet Gaillard (2012) describes how climate change distracts from these other development topics on Kiribati.

Meanwhile, academic literature sometimes uses climate change to mask wider development situations. Locke (2009) provides an important and detailed discussion of the range of development challenges facing Kiribati and Tuvalu, and the multiple reasons for internal and external migration. Mirroring statements made throughout the paper that attribute some migration to climate change, he concludes by emphasising climate change reasons: "there is a strong association between an increase in population density in small areas, sparked by climate change-induced migration, and a decline in human development indicators" (pp. 178-179). Yet the evidence presented does not prove that climate change-induced migration was or is happening. For instance, extreme weather on the islands is noted as influencing migration, but citations are not given linking that extreme weather to climate change. As Locke (2009) rightly notes for Kiribati, "Other than personal testimonies, migratory studies that disaggregate migratory influences are non-existent” (p. 175). Yet climate change, and the future challenges associated with it, are nonetheless used to diffuse the other development challenges happening now that are highlighted throughout the paper.

Migration potentially linked to climate change is indeed a SIDS-pertinent topic, especially for the future. Migration is presented as both a key consequence of, and an adaptation measure to, climate change impacting SIDS (e.g. Locke 2009). When climate change hazards are emphasised, suggesting that migration will be necessary because the islands will inevitably drown, deeper 
discussion indicating how and why migration decisions are made can be overlooked or underplayed (Bedford and Hugo 2012).

Many reasons exist why SIDS peoples choose to migrate, where they resettle, who pays for their resettlement, and the legal (including sovereignty) and resource management frameworks for new communities (e.g. Grote 2010). In fact, migration has always been important for SIDS peoples, such as on volcanic islands that erupted (e.g. Belshaw 1951; Haynes et al. 2008). This experience might not directly assist communities moving from islands which have not previously experienced such extensive migration, but experiences can be shared amongst SIDS to help each other learn and adjust. The different time scales for migrating under different volcano and climate change scenarios could indicate some differences in how to adjust regarding migration, but the differences should not be exaggerated (Kelman and Gaillard 2009). Climate change is not only a long-term hazard, because changes can come suddenly such as coral bleaching or a cyclone that is more intense due to higher sea surface temperatures. Volcanoes are not only short-term hazards because they can ramp up slowly and eruptive sequences can last decades.

The techniques and lessons from volcanoes and other hazards could be applied for climate change, yet rarely are (Kelman and Gaillard 2009). Instead, emphasising hazards (Section 3.1) separates volcanoes and climate change, despite a common social denominator that few SIDS peoples wish to be forced from their homes for any reason (e.g. Haynes et al. 2008). As Pacific island ambassadors to the United Nations declared with respect to climate change: 'We do not want to leave our land' (McNamara and Gibson 2009, 481). They nonetheless recognise that migration might be necessary and so they wish to migrate on their terms rather than having external migration processes forced upon them or waiting until a life-threatening emergency manifests. Reinforcing that attitude, Kiribati's Foreign Minister stated prior to the 2009 climate change negotiations: "We do not want to 
relocate as environmental refugees...We want to be able to relocate on merit and with dignity" (NZPA 2009, online).

Some literature (e.g. Adger and Barnett, 2005; Pilkey and Young 2009) describes how New Zealand started a new scheme to admit people from Tuvalu as part of the first wave of 'climate refugees'. The relevant scheme appears to be New Zealand's Pacific Access Category ${ }^{1}$, which is an agreement with Kiribati, Tonga, and Tuvalu to annually permit several dozen healthy and skilled citizens from each country to emigrate to New Zealand. Mentions of neither climate change nor environmental change were found in any of the official documentation, with the scheme instead describing that "Work opportunities, education and family are some of the reasons people choose to leave the Pacific Islands and start a new life in New Zealand, and many have found New Zealand a great place to live, work and raise families" (online) - followed by information on other ways of emigrating to New Zealand. That is, the wider development topic, irrespective of climate change, is SIDS peoples' migration for livelihoods. Climate change will certainly affect such migration, but cannot be taken to be the sole or principal cause or focus for migration (see also Foresight 2011).

For the Pacific, Bedford and Hugo (2012) provide an overview of population movements. The main reasons identified for Pacific islanders moving to Australia and New Zealand are family and jobs. Pacific peoples as migrants (Hau'ofa, 1993) is mirrored in the Caribbean. When Montserrat became nearly uninhabitable due to the volcanic eruption starting in 1995 and continuing today (Haynes et al. 2008), regional authors debated whether or not the islanders can and should just move, because mobility is part of their heritage (Howe 1997). These discussions are rarely acknowledged in the literature on migration and climate change, even though the notion that 'climate refugees' and 'environmental refugees' are misnomers is repeated in recent (e.g. Hartmann 2010) and older (e.g.

\footnotetext{
${ }^{1} \mathrm{http}: / / \mathrm{www}$. immigration.govt.nz/migrant/stream/live/pacificaccess
} 
Cooper 1998) literature. That has not stopped many from continuing to promote quantitative estimates of 'climate change refugees' with limited support for the numbers (see a critique of the quantitative estimates in Gemenne, 2011).

One implication of focusing on climate and climate change as the reason for migration, rather than multiple development challenges including but not limited to climate factors, is that the debate can become sidetracked-from actions to address all development challenges towards who is responsible for just a single topic, in this case climate change. If support were given to SIDS peoples for migrating on the basis of only climate change, then other vulnerabilities, emerging locally and externally, might not be acknowledged, let alone redressed. Whilst no peoples deserve to be forced migrants and whilst no country deserves to lose sovereignty due to external environmental change, development challenges facing SIDS exist beyond climate change and need to be dealt with, even if communities or countries move due to only climate change.

\section{Climate change shifts focus away from vulnerability reduction}

Recognising wider development challenges, as well as climate change, might allow space for climate change's hazards to become an 'opportunity', however unfortunate and unfair, to address underlying vulnerabilities. SIDS could become a 'barometer', not only for climate change impacts (Benwell 2011; INSNI 1999; Thompson 2008), but also for tackling climate change by building a less vulnerable society that deals with multiple development challenges simultaneously. Such research, debate, and implementation have long emerged from previous studies and practice on disaster risk reduction (e.g. Gaillard 2007, 2010; Hewitt 1983, 1997; Lewis 1999; Wisner et al. 2004, 2012) which could be applied to present-day vulnerability reduction. 
As one example from amongst many studies on pre- and post-disaster resettlement (e.g. Badri et al. 2006; Oliver-Smith 1986), after the 26 December 2004 tsunami disaster around the Indian Ocean, many groups adopted the tagline 'Build Back Better' for post-tsunami reconstruction. 'Build Back Better' refers to using post-disaster recovery and reconstruction as an opportunity to build sustainable communities without re-creating or exacerbating vulnerabilities. 'Build Back Better' has a pre-tsunami history (e.g. Monday 2002) and the principle underlies much theory and practice related to disasters as a development challenge (e.g. Copans 1975; Glantz 1976; Lewis 1999; Pelling 2003; Wisner et al. 2004, 2012), thereby giving climate change a solid foundation to build on.

The most prominent post-tsunami promoter, Clinton (2006), effectively defined the contemporary 'Build Back Better' agenda. The emphasis of 'Build Back Better' on local participation, as per standard development approaches, is important in terms of involving all genders (male, female, and non-traditional gender identities), all ages, people with disabilities, and representatives of ethnic, religious, caste, and cultural groups in the community, especially given the above discussion of community heterogeneity. Clinton (2006) is clear that local leadership and control are essential, especially to achieve fairness and equity which are other standard development tenets.

In the context of an entire SIDS community, island, or country migrating due to climate change (e.g. Stoutenburg 2011), 'Build Back Better' implies reconstructing in the new location with reduced vulnerabilities than in the original location to all hazards. Migrants should be given and should accept significant responsibility for decision-making during reconstruction. Yet for SIDS considering migration futures under climate change, it is precisely the local voices which tend to be most marginalised (Kelman 2010; McNamara 2009; Nurse and Moore 2007). As a proviso, Kennedy et al. (2008) note for 'Build Back Better' that "Community involvement is essential, but 
that does not necessarily mean community control" (p. 32) due to community heterogeneity and for ensuring that all community voices are considered. Fairness, equity, and community responsibility might have differences from local control of participation if power structures dictate that some locals dominate discussions and decisions.

Consequently, 'Build Back Better' due to climate change could be used as an opportunity to deal with ongoing development challenges, such as overcoming engrained power structures and promoting fairness and equity in SIDS communities. Major changes will happen during community reconstruction anyway, since many cultures including many from SIDS tie identity and culture to place and territory. Too many tangible and intangible elements of a community must be left behind when moving locations, opening up an opportunity to change other elements so that all vulnerabilities are tackled in tandem.

Cultural clashes can result, leading to questions about balancing different groups' interests in decision-making. For instance, capital punishment is eschewed in many western approaches to human rights, yet Tonga still retains whipping and death by hanging as possible crime punishments (Laws of Tonga 1988), even though those punishments are rarely (if ever) enacted. If new SIDS communities are created as part of responding to climate change, then that could be an opportunity to 'Build Back Better' by eliminating capital punishment and promoting gender and racial equity. That suggestion is subject to accusations that it imposes external imperialistic approaches and values. The premise of local participation could mean that the SIDS peoples choose their governance system themselves-even if the decision-making process in the new location is as exclusionary as it was in the original country. Consequently, development challenges, including the same vulnerabilities to hazards (including climate change), might remain in the new communities (see also Badri et al. 2006). 
For post-migration livelihoods in SIDS communities, can root causes of vulnerability be solved through 'Build Back Better'? The political economy of SIDS has been conceptualised as MIRAB meaning migration, remittances, aid, and bureaucracy (Bertram and Watters 1985) and variations/updates thereof (e.g. Bertram 1999; Poirine 1994). 'Build Back Better' could mean moving towards 'better' livelihood models, particularly reducing aid dependency and bureaucracy — and perhaps even reducing remittances. To support fairness, equity, and community responsibility, it is unclear who should judge what is a 'better' livelihood or livelihood model and the criteria to use for those judgements.

Attempts to answer such questions are being made regarding post-earthquake Haiti (USDS 2011), also a SIDS. Those attempts have been criticised for foisting on the people the same power structures that caused Haiti's vulnerability to earthquakes in the first place (Schuller and Morales 2012). Those dealing with climate change on SIDS could learn from this investigation into overcoming root causes of vulnerability after a disaster - and why inherent power structures do not always permit those root causes to be tackled. Migration and community reconstruction linked to climate change need to be wary of not rebuilding a community with similar vulnerabilities as before to all hazards.

Samoa potentially provides a good practice example regarding vulnerability reduction through tackling root causes, with climate change incorporated as one hazard amongst many (Daly et al. 2010). A process funded by the World Bank (but see also the critique by Le De 2011) initiated local participatory development activities through combining local and external knowledge in coastal villages to address climate-related hazards including climate change, as well as wider coastal management. District meetings integrated local perspectives from several villages to account for 
concerns at wider scales. The result was local coastal management plans further compiled into a national coastal vulnerability reduction strategy. Training national and local staff in participatory methods left behind a development legacy. Time will tell how successful this endeavour has been.

\section{Conclusions}

In the context of SIDS, this paper has argued that the contemporary privileging of climate change discourses has distracted from other prominent development challenges. As such, without denying the politics surrounding the topic (e.g. Betzold 2010), climate change has depoliticised many of those development challenges by not focusing on why vulnerabilities to all hazards are caused and perpetuated. This argumentation does not suggest that SIDS peoples are responsible for the vulnerabilities. In contrast, many of the vulnerabilities, historically and currently, are externally caused. Nor does this argumentation suggest that climate change as a hazard should be ignored. Climate change brings severe consequences for SIDS, but it is one of many development challenges with severe consequences for SIDS, including the potential for migration-which, for instance, volcanoes have already brought to some SIDS islands.

Where climate change results in migration from SIDS, then reconstructing the SIDS communities elsewhere necessitates dealing with the same wide-ranging and long-standing development concerns affecting SIDS irrespective of climate change. Examples noted include energy, water, gender equity, human rights, and land use. Otherwise, the same vulnerabilities could be reproduced in the new communities. The challenge is not so much addressing the hazard of climate change per se (although climate change mitigation activities are certainly essential), but is addressing why SIDS peoples often do not have the resources to resolve climate change and other development challenges themselves, on their own terms. That is, the fundamental challenge is vulnerability to all hazards. Sometimes the reasons emerge from within SIDS, such as the Maldivian ex-President 
highlighting climate change without noting other development topics as prominently. Sometimes the reasons are constructed externally, such as the international media presenting SIDS as hapless and helpless victims of climate change-even against the wishes of some SIDS peoples.

IPCC (2012) goes some way towards de-emphasising the external hazards and highlighting vulnerabilities, but there is much farther to go based on existing literature and knowledge. It is particularly important to understand better why climate change depoliticises through the apparent desire to focus on hazards at the expense of vulnerabilities. Partly, it is the severe impacts which climate change will bring, especially to SIDS, unless humanity takes appropriate action, with the latter clause often forgotten due to emphasising the severe (potential) impacts. Partly, it is the industry which has been built up around climate change and which needs to maintain momentum for itself (Arnall et al. 2013, this issue). Partly, it hails back to Hewitt's (1983) description of the appeal of focusing on hazards, in that making climate change 'appropriated and severed from its roots in the rest of material life' (p. 29) thereby diffuses responsibility for those causing climate change-even while accepting that climate change nonetheless has a major anthropogenic component!

Overall, the solution is not about needing to solve climate change first and foremost, nor of placing climate change as the most prominent development concern for SIDS. Instead, it is about placing climate change (as one hazard amongst many) high on the agenda alongside all the other development concerns-which still need to be solved irrespective of climate change. As demonstrated by SIDS, climate change has not changed vulnerability to hazards nor the marginalisation which SIDS experience, none of which can be addressed without accepting the politicisation contexts in which they exist. Instead, climate change has become a distraction from underlying vulnerability and lack of development. 


\section{References}

Adger N and Barnett J 2005 Compensation for climate change must meet needs Nature 436328

Arnall A, Kothari U, and Kelman I 2013 Geographical Journal Themed Section: Politics of climate change The Geographical Journal, this issue

Attzs M 2008 Natural disasters and remittances: Exploring the linkages between poverty, gender and disaster vulnerability in Caribbean SIDS Research paper no. 2008.61, UNU (United Nations University) WIDER, Helsinki

Badri S A, Asgary A, Eftekhari A R, and Levy J 2006 Post-disaster resettlement, development and change: a case study of the 1990 Manjil earthquake in Iran Disasters 30 451-68

\footnotetext{
Ballu V, Bouin M N, Siméoni P, Crawford W C, Calmant S, Boré J M, Kanas T, and Pelletier B 2012 Comparing the role of absolute sea-level rise and vertical tectonic motions in coastal flooding, Torres Islands (Vanuatu) PNAS 108 13019-22
}

Barnett J and Campbell J 2010 Climate Change and Small Island States: Power, Knowledge and the South Pacific Earthscan, London

Bedford R and Hugo G 2012 Population Movement in the Pacific: A Perspective on Future Prospects Department of Labour, Wellington 
Belshaw C 1951 Social Consequences of the Mount Lamington Eruption Oceania 21 241-53

Benwell R 2011 The Canaries in the Coalmine: Small States as Climate Change Champions The Round Table 100 199-211

Bertram G 1999 The MIRAB Model Twelve Years On The Contemporary Pacific 11 105-38

Bertram G and Watters R F 1985 The MIRAB Economy in South Pacific Microstates Pacific Viewpoint 26 497-519

Betzold C 2010 'Borrowing' Power to Influence International Negotiations: AOSIS in the Climate Change Regime, 1990-1997 Politics 30 131-48

Bunce M, Brown C, and Rosendo S 2010 Policy misfits, climate change and cross-scale vulnerability in coastal Africa: how development projects undermine resilience Environmental Science and Policy 13 485-97

Chambers R 1995 Poverty and livelihoods: whose reality counts? Environment and Urbanization 7 173-204

Clinton W J 2006 Lessons Learned from Tsunami Recovery: Key Propositions for Building Back Better United Nations, New York

Connell J 2003 Losing ground? Tuvalu, the greenhouse effect and the garbage can Asia Pacific Viewpoint 44 89-107 
Cooper J B 1998 Environmental Refugees: Meeting the Requirements of the Refugee Definition N.Y.U. Environmental Law Journal 6 480-529

Copans J ed 1975 Sécheresses et Famines du Sahel François Maspero, Paris

Daly M, Namouta P, Nelson F, and Kohlhase J 2010 Reducing the Climate Vulnerability of Coastal Communities in Samoa Journal of International Development 22 265-81

Deininger K 2003 Land Policies for Growth and Poverty Reduction World Bank and Oxford University Press, Washington, DC and Oxford

Dickinson W R 2009 Pacific Atoll Living: How Long Already and Until When? GSA Today 19 410

Dommen E and Hein P eds 1985 States, microstates and islands Croom Helm, London

Domroes M 2001 Conceptualising State-Controlled Resort Islands for an Environment-Friendly Development of Tourism: The Maldivian Experience Singapore Journal of Tropical Geography 22 $122-37$

Farbotko C 2005 Tuvalu and climate change: Constructions of environmental displacement in the Sydney Morning Herald Geografiska Annaler: Series B, Human Geography 87 279-93 
Farbotko C 2010 Wishful sinking: Disappearing islands, climate refugees and cosmopolitan experimentation Asia Pacific Viewpoint 51 47-60

Foresight 2011 Migration and Global Environmental Change: Final Project Report The Government Office for Science, London

Fulu E 2007 Gender, Vulnerability, and the Experts: Responding to the Maldives Tsunami Development and Change 38 843-64

Gaillard JC 2007 Resilience of traditional societies in facing natural hazards Disaster Prevention and Management 16 522-44

Gaillard JC 2010 Vulnerability, Capacity, and Resilience: Perspectives for Climate and Disaster Risk Reduction Journal of International Development 22 218-32

Gaillard JC 2012 The climate gap Climate and Development 4 261-64

Gemenne F 2011 Why the numbers don't add up: A review of estimates and predictions of people displaced by environmental changes Global Environmental Change 21S S41-9

Ghina F 2003 Sustainable Development In Small Island Developing States: The Case Of The Maldives Environment, Development and Sustainability 5 139-65

Glantz M H ed 1976 The Politics of Natural Disaster: The Case of the Sahel Drought Praeger, New York 
Glantz M H ed 1988 Societal Responses to Regional Climatic Change: Forecasting by Analogy Westview, Boulder

GNCSODR 2011 If We Do Not Join Hands: Views from the front line 2011, GNCSODR (Global Network of Civil Society Organisations for Disaster Reduction), Teddington

Grist N 2008 Positioning climate change in sustainable development discourse Journal of International Development 20 783-803

Grote J 2010 The Changing Tides of Small Island States Discourse - A Historical Overview of the Appearance of Small Island States in the International Arena Law and Politics in Africa, Asia and Latin America 2010/2 164-91

Hartmann B 2010 Rethinking Climate Refugees and Climate Conflict: Rhetoric, Reality and The Politics Of Policy Discourse Journal of International Development 22 233-46

Hau'ofa E 1993 A new Oceania: Rediscovering our sea of islands USP, Suva

Haynes K, Barclay J, and Pidgeon N 2008 The issue of trust and its influence on risk communication during a volcanic crisis Bulletin of Volcanology 70 605-21

Hewitt K ed 1983 Interpretations of calamity from the viewpoint of human ecology Allen \& Unwin, London 
Hewitt K 1997 Regions of Risk: A Geographical Introduction to Disasters Addison Wesley Longman, Essex

Howe D 1997 Perhaps Clare Short was right about golden elephants New Statesman 26 September 34

INSNI 1999 NGO statement on Small Island Developing States Programme of Action INSNI (International Network of Small Island Developing States and Indigenous Peoples (INSNI)) Caucus, New York

IPCC 2007 IPCC Fourth Assessment Report IPCC (Intergovernmental Panel on Climate Change), Geneva

IPCC 2012 The IPCC Special Report on Managing the Risks of Extreme Events and Disasters to Advance Climate Change Adaptation (SREX) IPCC (Intergovernmental Panel on Climate Change), Geneva

Jones P and Lea J P 2007 What Has Happened to Urban Reform in the Island Pacific? Some Lessons from Kiribati and Samoa Pacific Affairs 80 473-91

Kelman I 2010 Hearing local voices from Small Island Developing States for climate change Local Environment 15 605-19

Kelman I and Gaillard JC 2009 Challenges and Opportunities of Disaster-Related Public Anthropology Asian Journal of Environment and Disaster Management 1 119-39 
Kennedy J, Ashmore J, Babister E, and Kelman I 2008 The Meaning of 'Build Back Better': Evidence from Post-tsunami Aceh and Sri Lanka Journal of Contingencies and Crisis Management 16 24-36

King D 2004 Climate Change Science: Adapt, Mitigate, or Ignore? Science 303 176-7

Kothari U 2013 Political Discourses of Climate Change and Migration: Resettlement Policies in the Maldives The Geographical Journal, this issue

Laws of Tonga 1988 Criminal Offences Government of Tonga, Nuku'Alofa

Lazrus H 2009 Weathering the Waves: Climate Change Politics and Vulnerability in Tuvalu Unpublished PhD thesis Department of Anthropology, University of Washington

Le De L 2011 Post-Disaster Reconstruction Strategy: Opportunity or Opportunism? 2009 Tsunami in Samoa as a Case Study Unpublished Master's thesis School of Environment, University Of Auckland

Lewis J 1999 Development in disaster-prone places: studies of vulnerability Intermediate Technology Publications, London

Locke J T 2009 Climate change-induced migration in the Pacific Region: sudden crisis and longterm developments The Geographical Journal 175 171-80 
McGillivray M, Naudé W, and Santos-Paulino A U 2008 Policy Arena: Small Island States Development Challenges: Introduction Journal of International Development 20 481-85

McNamara K E 2009 Voices from the margins: Pacific ambassadors and the geopolitics of marginality at the United Nations Asia Pacific Viewpoint 50 1-12

McNamara K E and Gibson C 2009 'We do not want to leave our land': Pacific ambassadors at the United Nations resist the category of 'climate refugees' Geoforum 40 475-83

Méheux K, Dominey-Howes D, and Lloyd K 2007 Natural hazard impacts in small island developing states: A review of current knowledge and future research needs Natural Hazards 40 $429-46$

Moglia M, Perez P, and Burn S 2007 Water troubles in a Pacific atoll town Water Policy 10613 37

Monday J L 2002 Building Back Better: Creating a Sustainable Community after Disaster Natural Hazards Informer 2002/3, 1-12

Nakalevu T 2006 CV\&A: A Guide to Community Vulnerability and Adaptation Assessment and Action Secretariat of the Pacific Regional Environment Programme, Apia

Nunn P D, Hunter-Anderson R, Carson M T, Thomas F, Ulm S, and Rowland M J 2007 Times of Plenty, Times of Less: Last-Millennium Societal Disruption in the Pacific Basin Human Ecology $35385-401$ 
Nurse L and Moore R 2007 Critical considerations for future action during the second commitment period: a small islands' perspective Natural Resources Forum 31 102-10

NZPA 2008 Doomed Kiribati needs escape plan 5:00 AM Friday June 6, 2008 New Zealand Herald (http://www.nzherald.co.nz/nz/news/article.cfm?c_id=1\&objectid=10514735) Accessed 18 May 2012

NZPA 2009 Kiribati says NZ, Aust not doing enough 2:08 PM Thursday December 10, 2009 One News (http://tvnz.co.nz/world-news/kiribati-says-nz-aust-not-doing-enough-3249608) Accessed 19 July 2012

O'Keefe P, Westgate K, and Wisner B 1976 Taking the naturalness out of natural disasters Nature 260 566-67

Oliver-Smith T 1986 The Martyred City: Death and Rebirth in the Andes University of New Mexico Press, Albuquerque, New Mexico

Olowu D 2007 Environmental Governance Challenges in Kiribati: An Agenda for Legal and Policy Responses Law, Environment and Development Journal 3 259-69

Pelling M ed 2003 Natural Disasters and Development in a Globalizing World Routledge, London

Pelling M and Uitto J I 2001 Small Island Developing States: Natural Disaster Vulnerability and Global Change Environmental Hazards 3 49-62 
Pilkey O H and Young R 2009 The Rising Sea Island Press, Washington, DC

Poirine B 1994 Rent, Emigration and Unemployment in Small Islands: The MIRAB Model and the French Overseas Departments and Territories World Development 22 1997-2009

Rankey E C 2011 Nature and stability of atoll island shorelines: Gilbert Island chain, Kiribati, equatorial Pacific Sedimentology 58 1831-59

Schaeffer M, Hare W, Rahmstorf S, and Vermeer M 2012 Long-term sea-level rise implied by $1.5^{\circ} \mathrm{C}$ and $2^{\circ} \mathrm{C}$ warming levels Nature Climate Change $2867-70$

Schuller M and Morales P eds 2012 Tectonic Shifts: Haiti Since the Earthquake Kumarian Press, Sterling, Virginia

Sen A 1981 Poverty and Famines: An Essay on Entitlement and Deprivation Clarendon Press, Oxford

Shaw R, Pulhin J M, and Pereira J J eds 2010 Climate Change Adaptation and Disaster Risk Reduction: Issues and Challenges Emerald Group, Bingley

Solomon S, Plattner G K, Knuttic R, and Friedlingstein P 2009 Irreversible climate change due to carbon dioxide emissions PNAS 106 1704-9 
Steinberg T 2000 Acts of God: The Unnatural History of Natural Disaster in America Oxford University Press, New York

Stoutenburg J G 2011 Implementing a New Regime of Stable Maritime Zones to Ensure the (Economic) Survival of Small Island States Threatened by Sea-Level Rise The International Journal of Marine and Coastal Law 26 263-311

Thompson E 2008 Acceptance speech by Senator Elizabeth Thompson Recipient of 'The Champion of the Earth Award 2008' - Latin America and the Caribbean United Nations Environment Programme, Nairobi

Toth L T, Aronson R B, Vollmer S V, Hobbs J W, Urrego D H, Cheng H, Enochs I C, Combosch D J, van Woesik R, and Macintyre I G 2012 ENSO Drove 2500-Year Collapse of Eastern Pacific Coral Reefs Science 337 81-4

Turvey R 2007 Vulnerability Assessment of Developing Countries: The Case of Small-island Developing States Development Policy Review 25 243-64

UN 1994 Report of the Global Conference on the Sustainable Development of Small Island Developing States. Document A/CONF.167/9 United Nations, New York

UN 2005 Draft Mauritius strategy for the further implementation of the programme of action for the sustainable development of Small Island Developing States. Document A/CONF.207/CRP.7 United Nations, New York 
USDS 2011 Post-Earthquake USG Haiti Strategy: Toward Renewal and Economic Opportunity USDS (US State Department), Washington, DC

van Alphen K, Hekkert M P, and van Sark W G J H M 2008 Renewable energy technologies in the Maldives-Realizing the potential Renewable and Sustainable Energy Reviews 12 162-80

Walmsley J 2006 The Nature of Community: Putting Community in Place Dialogue 25 5-12

Webb A P and Kench P S 2010 The dynamic response of reef islands to sea-level rise: Evidence from multi-decadal analysis of island change in the Central Pacific Global and Planetary Change $72234-46$

Wisner B, Blaikie P, Cannon T, and Davis I 2004 At Risk: Natural Hazards, People's Vulnerability and Disasters, 2nd ed Routledge, London

Wisner B, Gaillard JC, and Kelman I eds 2012 Handbook of Hazards and Disaster Risk Reduction Routledge, Abingdon 
Table 1: Illustrative impacts of climate change on SIDS

Climate change leads to: $\quad$ That impacts: $\quad$ The impacts are exacerbated by:

Sea-level rise.

Freshwater.

Increased water consumption per

Storm/precipitation regime changing.

capita.

Changing air temperature.

Land-based food. Local preference for unhealthy

Invasive alien species.

imported foods, meaning increased

dependence on external food prices

and worsening population health.

Changing sea temperature. $\quad$ Sea-based food. $\quad$ External, commercial fisheries.

Invasive alien species.

Ocean acidification.

Coral reefs

Sediment run-off, plus using

dynamite and poison for fishing.

Less healthy coral reefs.

Coastal erosion.

Sediment run-off and relying on

Sea-level rise.

unsuitable structural defences.

Storm/precipitation regime changing. 